\title{
Nursing Students' Knowledge and Attitude toward Pain Management in Gaza Strip, Palestine
}

\author{
Mohammed Riad Abu Reyala* \\ College of Health Professions, Al Quds University, Gaza, Palestine
}

\begin{abstract}
Background: Pain is considered as one of the most common reasons that oblige people to seek medical care. Graduates in nursing have a vital role in administering medication and have an essential role in pain management. However, applying these roles require that nursing students attain an adequate knowledge and management toward pain. So, the present study was conducted to examine the level of nursing students' knowledge and attitude toward pain management in Gaza Strip.

Method: A quantitative cross-sectional survey was used. Two hundred and fourteen knowledge and attitudes survey regarding pain management were submitted to nursing students who studying in different universities and colleges in Gaza Strip and participated in this study. Data were analyzed with the Statistical Package for the Social Sciences software (SPSS; version 22).

Results: One hundred and ninety-one questionnaires were returned with response rate $90 \%$. The results of the study showed that a mean score of knowledge and attitude were (45.4\%). A significant difference in the mean was observed in regard to student's Grade Point Average, attending training courses concerned to pain management, reading books or journals about pain management, and frequency of using pain assessment tools $(P<0.05)$.

Conclusion: Nursing students had a deficit in knowledge and negative attitudes toward pain assessment and management. Thus, there is a need to design educational program related to pain management, and a thorough review of nursing core curriculum should be performed.
\end{abstract}

\section{Keywords}

Knowledge and Attitudes, Nursing students, Pain management, Gaza Strip

\section{Introduction}

Pain is considered one of the most common reasons that oblige people to seek medical care [1]. Inadequate pain management continues to be problematic for patients and public health issues worldwide $[2,3]$. The International Association for the Study of Pain defined pain as an "Unpleasant sensory and emotional experience associated with actual or potential tissue damage or described in terms of such damage" [4].

Furthermore, there is a growing awareness on the etiology of pain, together with the advancement of pharmacological management of pain, even with this awareness and pharmacological advancement, patients still experience intolerable pain which hampers the physical, emotional, and spiritual dimension of the health $[5,6]$. Thus, effective control of the pain is an important consideration for healthcare professionals to ensure good quality of care and it would be unfair to make the patients feel pain without suitable pain relief or to deliver treatment with high-quality and to increase patient's quality of life [7].

Graduates in nursing are the key players in administering medication and have an essential role in pain management. However, applying these roles requires that nursing students attain adequate knowledge and management toward pain based on the international standers in the nursing programs for both undergraduates and postgraduates $[8,9]$.

Furthermore, many issues may be influencing nurses ability to assess and manage pain such as insufficient pain information in educational courses in curricular context, lack of guidelines, policies, and continuous education relating to pain management in clinical field, the misunderstanding of the subjectivity nature of pain, using of inappropriate pain scales

*Corresponding author: Mohammed Riad Abu Reyala, College of Health Professions, Al Quds University, Gaza, Palestine

Accepted: March 24, 2020

Published online: March 26, 2020

Citation: Reyala MRA (2020) Nursing Students' Knowledge and Attitude toward Pain Management in Gaza Strip, Palestine. J Clin Anesth Pain Manag 4(1):101-106 
to patient characteristics, and not relying on patient self-report. These identified gaps in the literature indicate a need for a more detailed assessment of nursing students' knowledge and attitudes of pain assessment and management to identify the accurate nature and depth of their knowledge and attitudes $[10,11]$.

\section{Methods}

\section{Design and sample}

A quantitative, cross-sectional survey was conducted at four main universities and colleges (The Islamic University of Gaza, Al Azhar University- Gaza, University college of applied sciences, and Palestine college of nursing) in Gaza Strip. The target population was all fourth-year nursing students "baccalaureate" who are studying in these universities and colleges and who met the sample criteria and agreed to participate in the study. The total number of fourth-year nursing students in Gaza Strip are 480 students. The sample size was calculated by using raosoft sample calculator and was 214 nursing students, 191 of them are positively responded with a response rate of $90 \%$. "Simple random sampling".

\section{Study instruments}

Data were collected by using a questionnaire that contains informed consent, a demographic form, and modified nurses' knowledge and attitudes survey regarding pain (NKASRP), the original NKASRP was developed to reflect the standards for pain management from the American Pain Society, World Health Organization, and the Agency for Health Care Policy and Research. The first 24 items are true/false questions, items $25-38$ are multiple-choice questions, and items 39 and 40 are case studies. It includes aspects of pain assessment, pharmacological and non-pharmacological interventions and attitudes towards pain management [12].

\section{Ethical considerations}

Ethical approval for the study was obtained from the head of faculty of nursing departments at non-governmental universities and colleges, administrative approval from Ministry of health for data collection at governmental college, and all students participant were asked to sign consent forms after reading an information sheet.

\section{Data analysis}

Data were analyzed using the Statistical Package for Social Sciences (SPSS) software version 22. Descriptive statistics, including frequencies, percentages, means, and standard deviations were used to describe the demographic characteristics. Moreover, the percentage of the correct answers for each item was calculated. Independent sample t test, one-way ANOVA tests were used to detect differences in the mean total score of knowledge and attitude in relation to demographic and personal characteristics. A p-value of $<0.05$ was considered statistically significant.

\section{Results}

A total of 191 nursing students completed and returned
Table 1: Distribution of the studied sample according to their sociodemographic $(n=191)$.

\begin{tabular}{|c|c|c|}
\hline Characteristics & n & $(\%)$ \\
\hline \multicolumn{3}{|l|}{ Gender } \\
\hline Male & 72 & 33.7 \\
\hline Female & 119 & 62.3 \\
\hline \multicolumn{3}{|l|}{ Marital Status } \\
\hline Single & 155 & 81.2 \\
\hline Married & 29 & 15.1 \\
\hline Divorced & 7 & 3.7 \\
\hline \multicolumn{3}{|l|}{ GPA } \\
\hline Excellent & 29 & 15.2 \\
\hline Very Good & 87 & 45.5 \\
\hline Good & 75 & 39.3 \\
\hline \multicolumn{3}{|l|}{ Family monthly income } \\
\hline Less than 1000 NIS & 22 & 11.5 \\
\hline $1000-2000$ NIS & 121 & 63.4 \\
\hline More than 2000 NIS & 48 & 25.1 \\
\hline \multicolumn{3}{|l|}{ University or College } \\
\hline The Islamic university & 81 & 42.4 \\
\hline Al Azher university & 40 & 20.9 \\
\hline University college of applied sciences & 27 & 14.2 \\
\hline Palestine college of nursing & 43 & 22.5 \\
\hline \multicolumn{3}{|c|}{ Attending training courses concerned to pain management } \\
\hline Yes & 119 & 62.3 \\
\hline No & 72 & 37.7 \\
\hline \multicolumn{3}{|c|}{ Reading books or journals about pain management } \\
\hline Yes & 113 & 59.2 \\
\hline No & 78 & 40.8 \\
\hline \multicolumn{3}{|l|}{ Frequency of using pain assessment tools } \\
\hline Yes & 93 & 48.7 \\
\hline No & 98 & 51.3 \\
\hline
\end{tabular}

NIS: New Israeli Shekel; GPA: Grade Point Average.

the study questionnaire. As shown in Table 1, 62.3\% of the participants were female, $81.2 \%$ of them were single, and $45.5 \%$ have a very good GPA. In addition, more than half of the students have family monthly income less than $1000 \mathrm{NIS}$, and $42.4 \%$ of them studying at the Islamic university. Furthermore, $62.3 \%$ of the students' nurses attended training courses concerned to pain management. Also, $59.2 \%$ of the participants were reading journals or books regarding pain management. Moreover, $48.7 \%$ of the students' nurses are frequently using pain assessment tools.

Students were asked to answer 24 true/false, and 18 multiple-choice questions. Frequency and percentage of correct answers are shown in (Table 2), and it was found that the total mean score of nursing students' knowledge and attitudes regarding pain management was $45.4 \%$. The lowest score was $31.4 \%$, and the highest score $64.4 \%$. Furthermore, since the 
Table 2: Nursing Students' Knowledge and Attitudes Regarding Pain Management.

\begin{tabular}{|c|c|c|c|c|}
\hline \multirow{2}{*}{ No. } & \multirow{2}{*}{ Item } & \multirow{2}{*}{ Mean (SD) } & \multicolumn{2}{|c|}{ Correct responses } \\
\hline & & & n & $\%$ \\
\hline \multicolumn{5}{|c|}{ True or false questions } \\
\hline 1 & Vital signs are always reliable indicators of the intensity of a patient's pain. & $0.46(0.500)$ & 88 & 46.1 \\
\hline 2 & $\begin{array}{l}\text { Because their nervous system is under developed, children under two years of age have } \\
\text { decreased pain sensitivity and limited memory of painful experiences. }\end{array}$ & $0.50(0.501)$ & 95 & 49.7 \\
\hline 3 & Patients who can be distracted from pain usually do not have severe pain. & $0.54(0.499)$ & 104 & 54.5 \\
\hline 4 & Patients may sleep in spite of severe pain. & $0.45(0.498)$ & 85 & 44.5 \\
\hline 5 & $\begin{array}{l}\text { Aspirin and other non-steroidal anti-inflammatory agents are NOT effective analgesics } \\
\text { for painful bone metastases. }\end{array}$ & $0.47(0.500)$ & 89 & 46.6 \\
\hline 6 & $\begin{array}{l}\text { Respiratory depression rarely occurs in patients who have been receiving stable doses } \\
\text { of opioids over a period of months. }\end{array}$ & $0.38(0.486)$ & 72 & 37.7 \\
\hline 7 & $\begin{array}{l}\text { Acetaminophen } 650 \mathrm{mg} \text { PO is approximately equal in analgesic effect to codeine } 32 \mathrm{mg} \\
\text { PO. }\end{array}$ & $0.60(0.492)$ & 114 & 59.7 \\
\hline 8 & $\begin{array}{l}\text { Combining analgesics that work by different mechanisms (e.g., combining an opioid } \\
\text { with an NSAID) may result in better pain control with fewer side effects than using a } \\
\text { single analgesic agent. }\end{array}$ & 0.55 (0.499) & 105 & 55.0 \\
\hline 9 & The usual duration of analgesia of morphine IV is $4-5$ hours. & $0.49(0.501)$ & 93 & 48.7 \\
\hline 10 & $\begin{array}{l}\text { Research shows that promethazine (Phenergan) is a reliable potentiates of opioid } \\
\text { analgesics. }\end{array}$ & $0.40(0.491)$ & 76 & 39.8 \\
\hline 11 & $\begin{array}{l}\text { Patients with a history of substance abuse should not be given opioids for pain because } \\
\text { they are at high risk for repeated addiction. }\end{array}$ & $0.43(0.496)$ & 82 & 42.9 \\
\hline 12 & $\begin{array}{l}\text { Beyond a certain dosage of morphine increases in dosage will NOT provide increased } \\
\text { pain relief. }\end{array}$ & 0.55 (0.499) & 105 & 55.0 \\
\hline 13 & Elderly patients cannot tolerate opioids for pain relief. & $0.50(0.501)$ & 96 & 50.3 \\
\hline 14 & $\begin{array}{l}\text { Patients with pain should be encouraged to endure as much pain as possible before } \\
\text { resorting to a pain relief measure. }\end{array}$ & $0.36(0.482)$ & 69 & 36.1 \\
\hline 15 & $\begin{array}{l}\text { Children less than } 11 \text {-years-old cannot reliably report pain, so nurses should rely solely } \\
\text { on the parent's assessment of the child's pain intensity. }\end{array}$ & $0.48(0.501)$ & 91 & 47.6 \\
\hline 16 & Patients' spiritual beliefs may lead them to think pain and suffering are necessary. & $0.52(0.501)$ & 100 & 52.4 \\
\hline 17 & $\begin{array}{l}\text { After an initial dose of opioid analgesic is given, subsequent doses should be adjusted in } \\
\text { accordance with the individual patient's response. }\end{array}$ & $0.41(0.493)$ & 78 & 40.8 \\
\hline 18 & $\begin{array}{l}\text { The child/adolescent should be advised to use non-drug techniques alone rather than } \\
\text { concurrently with pain medications. }\end{array}$ & $0.38(0.487)$ & 73 & 38.2 \\
\hline 19 & $\begin{array}{l}\text { Giving patients sterile water by injection (placebo) is a useful test to determine if the } \\
\text { pain is real. }\end{array}$ & $0.53(0.500)$ & 102 & 53.4 \\
\hline 20 & $\begin{array}{l}\text { Vicodin (hydrocodone } 5 \mathrm{mg}+\text { acetaminophen } 500 \mathrm{mg} \text { ) PO is approximately equal to } \\
5-10 \mathrm{mg} \text { of morphine PO. }\end{array}$ & $0.64(0.480)$ & 123 & 64.4 \\
\hline 21 & $\begin{array}{l}\text { If the source of the patient's pain is unknown, opioids should not be used during the } \\
\text { pain evaluation period, because this could mask the ability to correctly diagnose the } \\
\text { cause of pain. }\end{array}$ & $0.43(0.496)$ & 82 & 42.9 \\
\hline 22 & $\begin{array}{l}\text { Anticonvulsant drugs such as gabapentin (Neurontin) produce optimal pain relief after } \\
\text { a single dose. }\end{array}$ & $0.60(0.491)$ & 115 & 60.2 \\
\hline 23 & Benzodiazepines are not effective pain relievers unless the pain is due to muscle spasm. & $0.36(0.482)$ & 69 & 36.1 \\
\hline 24 & $\begin{array}{l}\text { Narcotic/opioid addiction is defined as a chronic neurobiological disease, characterized } \\
\text { by behaviors that include one or more of the following: Impaired control over drug use, } \\
\text { compulsive use, continued use despite harm, and craving. }\end{array}$ & $0.49(0.501)$ & 94 & 49.2 \\
\hline
\end{tabular}




\begin{tabular}{|c|c|c|c|c|}
\hline 25. & $\begin{array}{l}\text { The recommended route of administration of opioid analgesics for patients with } \\
\text { continuous persistent pain is: }\end{array}$ & $0.42(0.500)$ & 80 & 41.9 \\
\hline 26. & $\begin{array}{l}\text { The recommended route administration of opioid analgesics for patients with brief, } \\
\text { severe pain of sudden onset such as trauma or postoperative pain is }\end{array}$ & $0.50(0.501)$ & 96 & 50.3 \\
\hline 27. & $\begin{array}{l}\text { Which of the following analgesic medications is considered the drug of choice for the } \\
\text { treatment of prolonged moderate to severe pain for cancer patients? }\end{array}$ & $0.38(0.486)$ & 72 & 37.7 \\
\hline 28. & $\begin{array}{l}\text { Which of the following IV doses of morphine administered over a 4-hour period would } \\
\text { be equivalent to } 30 \mathrm{mg} \text { of oral morphine given q } 4 \text { hours? }\end{array}$ & $0.41(0.493)$ & 78 & 40.8 \\
\hline 29. & Analgesics for post-operative pain should initially be given & $0.45(0.498)$ & 85 & 44.5 \\
\hline 30. & $\begin{array}{l}\text { A patient with persistent cancer pain has been receiving daily opioid analgesics for } 2 \\
\text { months. Yesterday the patient was receiving morphine } 200 \mathrm{mg} / \text { hour intravenously. Today } \\
\text { he has been receiving } 250 \mathrm{mg} / \text { hour intravenously. The likelihood of the patient dev }\end{array}$ & $0.57(0.497)$ & 108 & 56.5 \\
\hline 31. & $\begin{array}{l}\text { The most likely reason a patient with pain would request increased doses of pain } \\
\text { medication is }\end{array}$ & $0.35(0.477)$ & 66 & 34.6 \\
\hline 32. & Which of the following is useful for treatment of cancer pain? & $0.55(0.499)$ & 105 & 55.5 \\
\hline 33. & The most accurate judge of the intensity of the patient's pain is & 0.55 (0.499) & 105 & 55.0 \\
\hline 34. & How likely is it that patients who develop pain already have drug abuse problem? & $0.40(0.492)$ & 77 & 40.3 \\
\hline 35. & The time to peak effect for morphine given IV is & $0.35(0.478)$ & 67 & 35.1 \\
\hline 36. & The time to peak effect for morphine given orally is & $0.31(0.465)$ & 60 & 31.4 \\
\hline 37. & $\begin{array}{l}\text { Following abrupt discontinuation of an opioid, physical dependence is manifested by } \\
\text { the following: }\end{array}$ & $0.37(0.485)$ & 71 & 37.2 \\
\hline 38. & Patients most able to endure pain: & $0.43(0.497)$ & 83 & 43.5 \\
\hline \multicolumn{5}{|c|}{ Case studies } \\
\hline 39. A & $\begin{array}{l}\text { On the patient's record you must mark his pain on the scale below. Circle the number } \\
\text { that represents your assessment of Ahmed's pain: }\end{array}$ & $0.32(0.469)$ & 62 & 32.5 \\
\hline 39. B & $\begin{array}{l}\text { Your assessment, above, is made two hours after he received morphine } 2 \text { mg IV. Half } \\
\text { hourly pain ratings following the injection ranged from } 6 \text { to } 8 \text { and he had no clinically } \\
\text { significant respiratory depression, sedation, or other untoward side effects. He has }\end{array}$ & $0.39(0.490)$ & 75 & 39.3 \\
\hline 40. A & $\begin{array}{l}\text { On the patient's record you must mark his pain on the scale below. Circle the number } \\
\text { that represents your assessment of Mohammed's pain: }\end{array}$ & $0.36(0.482)$ & 69 & 36.1 \\
\hline 40. B & $\begin{array}{l}\text { Your assessment, above, is made two hours after he received morphine } 2 \mathrm{mg} \text { IV. Half } \\
\text { hourly pain ratings following the injection ranged from } 6 \text { to } 8 \text { and he had no clinically } \\
\text { significant respiratory depression, sedation, or other untoward side effects. He has }\end{array}$ & $0.43(0.496)$ & 82 & 42.9 \\
\hline
\end{tabular}

NSAID: Non-steroidal anti-inflammatory drug; IV: Intravenous; PO; By mouth, PRN; Pro re nata.

Table 3: Differences between groups for selected characteristics in knowledge and attitude with regard pain management (Independent sample t test).

\begin{tabular}{|l|l|l|l|l|}
\hline Characteristics & \multicolumn{1}{|l|}{ n } & Mean (SD) & \multicolumn{2}{|l|}{ P value } \\
\hline Gender & 72 & $19.13(4.90)$ & 0.878 \\
\hline Male & 199 & $19.02(4.97)$ \\
\hline Female & 119 & $20.03(5.35)$ \\
\hline Attending training courses concerned to pain management & 72 & $17.47(3.66)$ \\
\hline Yes & & $0.000^{*}$ \\
\hline No & 113 & $20.36(5.03)$ \\
\hline Reading books or journals about pain management & 78 & $17.19(4.15)$ \\
\hline Yes & & $0.000^{*}$ \\
\hline No & 93 & $20.21(5.38)$ \\
\hline Frequency of using pain assessment tools & 98 & $17.97(4.22)$ \\
\hline Yes & & $0.002^{*}$ \\
\hline No & & \\
\hline
\end{tabular}

${ }^{*} \mathrm{P}$ value is significant $\leq 0.05$ 
Table 4: Differences between groups for selected characteristics in knowledge and attitude with regard pain management (One-way ANOVA).

\begin{tabular}{|l|l|l|l|}
\hline Characteristics & n & Mean (SD) & P value \\
\hline Marital Status & 155 & $19.20(5.14)$ & \\
\hline Single & 29 & $18.55(3.16)$ & 0.742 \\
\hline Married & 7 & $18.28(6.67)$ & \\
\hline Divorced & \multicolumn{3}{|l|}{} \\
\hline GPA & 29 & $23.96(4.79)$ & \\
\hline Excellent & 87 & $18.70(4.91)$ & \multirow{2}{*}{$0.000^{*}$} \\
\hline Very Good & 75 & $17.60(3.75)$ & \\
\hline Good & \multicolumn{2}{|l|}{} \\
\hline Family monthly income & 22 & $18.40(5.67)$ & \\
\hline Less than 1000 NIS & 121 & $19.46(4.71)$ & \multirow{2}{*}{0.350} \\
\hline 1000-2000 NIS & 48 & $18.37(5.12)$ & \\
\hline More than 2000 NIS & & & \\
\hline
\end{tabular}

${ }^{*} \mathrm{P}$ value is significant $\leq 0.05$

mean score was $45.4 \%$, and it's lower than $60 \%$, This means that nurses' knowledge and attitudes level were very low. Moreover, the majority of participants $86.5 \%$ had less than $60 \%$ of correct answers, while $12.5 \%$ of nurses their scores were between $60-79 \%$, however, only $1 \%$ of nurses passed with a score of $80 \%$ or greater in NKASRP scores.

Table 3 showed that the students who are attending training courses, reading books or journals, and frequency of using pain assessment tools have significantly higher mean level of knowledge and attitude than who did not. Moreover, there is no significant statistical difference in the level of nursing students' knowledge and attitude score with regard to their gender $(p>0.05)$.

Table 4 showed that there is a significant statistical difference in the level of nursing students' knowledge and attitude score with regard to their GPA $(p<0.05)$. Tukey Post hoc was conducted to know the differences between which groups, the test shows that the difference is between the students who have excellent and very good GPA in favor to those who have an excellent GPA. Moreover, statistical analysis revealed that there were no significant differences found in the students' mean scores in terms of marital status and family monthly income.

\section{Discussion}

The study was designed to assess nursing students' knowledge and their attitude toward pain management at Gaza Strip. Nursing students had a mean percentage of correct answers of $45.4 \%$ on the NKASRP indicating lack of knowledge and attitudes towards pain management. The results of this study are congruent with study conduct by Al Khalaileh and Al Qadire (2013) who found that the students demonstrated a poor understanding of pain knowledge and attitudes, with their KASRP being 16 out of 40 (SD $=5.1)$, which translates to $40 \%$ [13]. Also, the results consistent with Chan \& Hamamura (2016) who stated that the mean score for all participants was 20.9 which translates to $52.3 \%$, indicating that the students' knowledge and attitudes were suboptimal [14]. Moreover, the current study agreed with Al-Khawaldeh, et al. (2013) who said that students demonstrated a poor understanding of pain knowledge and attitudes with a KASRP score of $34.1 \%$ (SD =9.9) [15], and consistent with Alsaqri (2018) who found that nursing students have a lack of knowledge and attitudes towards pain management and the mean correct score for the entire scale was $41.8 \%$ (SD = 3.71) [16]. Furthermore, the current study is consistent with the results of Karman, et al. (2018) who stated that the mean score of the NKASRP was $15.85 \pm 3.25 \%$ (poor level of pain knowledge and attitude) [17]. And similar to the result of study conduct by Hroch (2017) who found that the mean score of the NKASRP was $66.7 \%$ and the major areas of weakness in pain knowledge and attitudes were related to understanding populations at risk of respiratory depression after receiving an opioid, dosage calculations, medication administration and pharmacology [18].

The result of this study showed that there was a significant statistical difference in the level of nursing students' knowledge and attitude score with regard to attending training courses concerned to pain management, this result is agreed with result of Al-Khawaldeh, et al. (2013) who found that there was a significant statistical difference in the students' scores related to pain management training [15]. On the contrary, this result is inconsistent with study of Al Khalaileh and Al Qadire (2013) who found that there was no significant statistical difference in the mean of total knowledge and attitude scores between students who received pain education and those who did not [13]. Also, the result of the current study disagreed with Alsaqri (2018) who stated that there was no significant statistical difference found in the students' mean scores in terms of attending a training course on pain management [16].

Moreover, the result of this study showed that there was a significant statistical difference in the level of nursing students' knowledge and attitude score with regard to frequency of using pain assessment tools, this result is agreed with study of Al-Khawaldeh, et al. (2013) who found that there was significant statistical difference in the students' scores related to frequency of using pain assessment tools and revealed that students who reported that they used pain assessment tools more frequently had significantly higher scores than students who reported that they never or rarely use pain assessment tools [15]. Also, this result is consistent with study of Alsaqri (2018) who stated that there was significant statistical difference related to the frequency of using pain scales and revealed students who use pain scales more frequently had significantly higher KASRP scores [16].

\section{Conclusion}

The findings of this current study suggest that nursing students have serious knowledge deficits and erroneous beliefs that may influence effective management of patients' pain. So, the nursing students in the universities and colleges of 
Gaza Strip require educational program and continues training regards pain management, a thorough review of nursing core curriculum at under-graduate level should be performed to ensure the content of educational modules provide adequate, relevant and appropriate information and subsequently equipping nursing students to effectively manage pain, encourage nursing students and motivate them to reading books and journal about pain assessment and management, enhancing the use of pain management tools by students in practical training, and work collaboratively with local, regional, and national organizations related to pain management awareness, research, and support for nursing students.

\section{Acknowledgments}

The author would like to express his appreciation to the all nursing students at the selected university and colleges for their cooperation and full support during data collection; Palestinian Ministry of Health and the administrations of university and colleges for giving permission for data collection, respectively.

\section{Financial Support and Sponsorship}

Nil.

\section{Conflicts of Interest}

There are no conflicts of interest.

\section{References}

1. Al-Khawaldeh, O, Al-Hussami, M Darwad (2013) Knowledge and attitudes regarding pain management among Jordanian nursing students. Nurse Educ Today 33: 339-345.

2. Al-Shaer D, Hill PD, Anderson M (2011) Nurses knowledge and attitudes regarding pain assessment and intervention. Medsurg Nurs 20: 7-11.

3. Wysong PR (2012) Nurses' beliefs and self-reported practices related to pain assessment and nonverbal patients. Pain Manag Nurs 15: 176-185.

4. (2017) International Association for the Study of Pain. IASP Taxonomy.

5. Eaton LH, Meins AR, Mitchell PH, et al. (2015) Evidence-based practice beliefs and behaviors of nurses providing cancer pain management: A mixed-methods approach. Oncol Nurs Forum 42: 165-173.
6. Pereira Dames LJ, Herdy Alves V, Pereira Rodrigues D, et al. (2016) Nurses' practical knowledge on the clinical management of neonatal pain: A descriptive study. Online Brazilian Journal of Nursing 15: 393-403.

7. Marwan Rasmi Issa, Adel Musbah Awajeh, Firas Shehadeh Khraisat (2017) Knowledge and attitude about pain and pain management among critical care nurses in a tertiary hospital. Journal of Intensive and Critical Care 3: 1.

8. Sulosaari V, Suhonen R, Leino-Kilpi H (2011) An integrative review of the literature on registered nurses' medication competence. J Clin Nurs 20: 464-478.

9. Ung A, Salamonson Y, Hu W, et al. (2016) Assessing knowledge, perceptions and attitudes to pain management among medical and nursing students: A review of the literature. $\mathrm{Br} J$ Pain 10: 8-21.

10. Ferrell BR, Coyle N, Paice JA (2015) Oxford Textbook of Palliative Nursing. Oxford University Press.

11. Miftah R, Tilahun W, Fantahun A, et al. (2017) Knowledge and factors associated with pain management for hospitalized children among nurses working in public hospitals in Mekelle City, North Ethiopia: Cross sectional study. BMC Res Notes 10: 122.

12. Ferrell BR, McCaffery M (2014) City of Hope. Knowledge and Attitudes Survey Regarding Pain.

13. Khalaileh MA, Qadire MA (2013) Pain management in Jordan: Nursing students' knowledge and attitude. Br J Nurs 22: 12341240.

14. Chan JC, Hamamura T (2016) Emotional intelligence, pain knowledge, and attitudes of nursing students in Hong Kong. Pain Manag Nurs 17: 159-168.

15. Al-Khawaldeh O, Al-Hussami M, Darawad M (2013) Knowledge and attitudes regarding pain management among Jordanian nursing students. Nurse Educ Today 33: 339-345.

16. Alsaqri SH (2018) Nursing student's knowledge and attitudes toward pain management at Hail University, Saudi Arabia. IJAAS 5: 75-81.

17. Karaman E, Dogru B, Yildirim Y (2018) Knowledge and attitudes of nursing students about pain management. AGRI PAIN 31: 7078.

18. Hroch J (2017) Nursing student's knowledge and attitudes about pain. Queen's University, Canada.

DOI: $10.36959 / 377 / 338$

Copyright: (C) 2020 Reyala MRA. This is an open-access article distributed under the terms of the Creative Commons Attribution License, which permits unrestricted use, distribution, and reproduction in any medium, provided the original author and source are credited. 